\title{
KÖZELSÉG ÉS REGIONÁLIS KLASZTEREK: A SZOFTVERIPAR SZEGEDEN
}

\author{
(Proximimty and Regional Clusters: \\ Software Industry in Szeged)
}

\begin{abstract}
VAS ZSÓFIA
Kulcsszavak:

földrajzi és kapcsolati közelség klaszter szoftveripar Szeged és vanzáskörzete

Az 1990-es években a modern információs és kommunikációs technológiák megjelenésével a tóvolság gazdasági életben betöltött szerepe átalakult. Az információ és tudás áramlásában a földrajzi közelség korábbi kulcsszerepe meggyengült, egymástól távoli ïzleti partnerek is sikeresen együtt tudnak müködni, pl. az innovativ vállalati szervezödések esetében. A földrajzi közelség mellett megjelent a 'kapcsolati közelség', ami az internetes hálókon alapuló együttmüködésekre jellemzỏ. A felmérések szerint a földrajzi és kapcsolati közelség elönyeire épülve a kevésbé fejlett régiók nagyvárosaiban is létrejöhetnek innovatív klaszterek, pl. a szoftveriparban.

Tanulmányunkban azt vizsgáljuk, hogy a Dél-alföldi régió tudásszigetében, Szegeden és vonzáskörzetében a szoftveripar klaszteresedésének milyen jellemzöi ragadhatók meg. Egy potenciális klaszter, jelen esetben a szoftveripar földrajzi koncentrációjának, térségi bázisának feltérképezésére a lokációs hányados gyakran alkalmazott módszer. Mig a tényleges együttmüködések megismerésére a klaszter alapját jelentö vállalati kör kérdöivezése ad lehetöséget.
\end{abstract}

\section{Bevezetés}

Napjainkra egyértelmüvé vált, hogy a tudásalapú gazdaság fejlődésének motorját jelentő klaszterek létrejötte nem csak egy "gyorsan múló divat”. A klaszter egy sikeres válasz a globális verseny kihívásaira, amely biztosítja a vállalatok tartós versenyelőnyeinek megerősődését. A klaszter egy adott iparág földrajzilag közel elhelyezkedő szervezeteinek innovatív cél érdekében kialakult szerveződése, amely hozzájárul a térség versenyképességének növekedéséhez és az innovációs képesség és készség javulásához (Porter 1990; 2000). A klaszter egy olyan összetett üzleti és nem üzleti elemekből álló kapcsolatrendszer, ahol a vállalati előnyök nem kizárólag a földrajzi közelségből erednek. A klaszterek sikeres gazdaságfejlesztési eszkőzként jelennek meg a fejlett országokat követően a fejlỏdő országokban is. Fejlesztésükre az Európai Unió és a tagállamok regionális és innovációs politikája kitüntetett figyelmet fordít, feltérképezésüket is kiemelt célként kezelik, mely feladatot az Európai Unióban az European Cluster Observatory hivatott ellátni.

Az internet, a mobil telefon stb. használatával az információ és a tudás terjedésének új csatornái jelentek meg, a távoli partnerek is „közel kerültek” egymáshoz, lehetôvé vált a távoli helyek szervezetei közötti tudásalapú kapcsolatok hatékony müködtetése. A kapcsolati hálók, a 'virtuális közelség' szerepének átértékelódését 
az 1990-es években megjelenő modern infokommunikációs eszközök erösítették fel. A tudásalapú tevékenységeknél a földrajzi közelségen kívül más 'közelségek', a 'kapcsolati tér', a 'hálózatok' stb. is a vizsgálatok előterében állnak. A 'közelség' átértékelödő szerepének elötérbe kerülése a regionális tudományi szakirodalomban is megfigyelhetö, a globalizációs folyamatok következtében átalakuló földrajzi és kapcsolati (szervezett) közelség jellemzőit alapos kutatások próbálják feltárni (Kirat-Lung 1999; Boschma 2005).

A közelség 'megkettőződése', a kétféle közelség együttes fellépése a klaszterek elemzésében és tudatos fejlesztésében újfajta megközelítést jelentett: nem csak a vállalatok térbeli koncentrációjából, földrajzi közelségéböl eredỏ elönyök vizsgálata vált szükségessé, hanem azok „kapcsolati” térben való elemzése is (Torre-Rallet 2005; LagendijkLorentzen 2007).

Az információs technológia (IT) a tudásalapú gazdaság egyik kulcsfontosságú pillére, hangsúlyos szereppel bírva az Európai Unió stratégiai fejlesztési programjaiban is. Az IT, így a szoftveripar olyan nemzetközi húzóágazattá vált, amely hozzájárul az információs társadalom gyors fejlödéséhez, elengedhetetlenné válva az üzleti és nem üzleti tevékenységek végzéséhez. A közelség jellemzőinek átalakulásával a szoftveripari klaszterek vizsgálata is új értelmet kapott.

Magyarországon az IT területén müködö klaszterek, pl. szoftveripari klaszterek kialakulásában is a közelség szerepe megváltozott. E jelenség felismerésének és vizsgálatának szükségességét támasztják alá a nemzetközi tapasztalatok is, amelyeket érdemes adaptálni, föleg a kevésbé fejlett országokban létrejött szoftveripari klaszterek esetében. Alapvetö kérdés, hogy a kevésbé fejlett Dél-alföldi régióban a „tudásszigetként” jellemezhető Szegeden megerősödhet-e a szoftveripar? A közelségnek milyen hatásai figyelhetök meg a tudásintenzív (szoftveripari) cégek együttmüködésében Szegeden?

Jelen tanulmányban ${ }^{1}$ a szegedi szoftveripar klaszteresedését vizsgáljuk. A közelség szakirodalmának áttekintése után a regionális klaszterek és a közelség szerepét elemezzük, kitérve adaptálható nemzetközi tapasztalatokra. A szoftveripar földrajzi koncentrációját a lokációs hányadossal, a klaszter-feltérképezés szokásos mutatójával vizsgáljuk. Ezt követően a vállalatok kérdőíves megkeresésével próbáljuk feltárni a földrajzi közelség szükségességét és a kapcsolati közelség meglétét és intenzitását.

\section{Közelség közgazdasági értelmezése}

Az elmúlt évtizedekben a globalizációs folyamatok új térszerveződés kialakulásához vezettek, és egyértelmủvé vált, hogy a globális versenyben kiemelkedő fontossággal bír a gazdasági tevékenységek földrajzi koncentrációja, amely a vállalatok tartós versenyelőnyeinek forrását is jelenti (Lengyel-Rechnitzer 2004). A gazdasági összefüggésekben vizsgált közelség fogalmát egészen az 1990-es évekig a hagyományos értelemben vett fizikai, földrajzi kis távolságként értelmezték. Az infokommunikációs eszközök használatának terjedésével a kapcsolatteremtés új formái 
jelentek meg, és a sikeresen megvalósult tudásalapú kiszervezések (outsourcing) száma is egyre nőtt. A kiszervezés egyik jeles példája az indiai szoftveripari vállalatok köre Bangaloreban, amelyek az amerikai szoftveripari cégek megbízásából fejlesztenek, folyamatos kapcsolatban állva megbízóikkal.

Az evolúciós közgazdaságtan mutatott rá arra, hogy a közelség fogalma a földrajzi szomszédságnál sokkal összetettebb, és a tudásteremtés és -terjedés folyamatában más szempontokat is vizsgálni kell (Boschma 2005). A ,francia iskola" (French School of Proximity Dynamics) kutatói a közelség két alapvető típusát különböztették meg (Kirat-Lung 1999; Torre-Gilly 2000; Torre-Rallet 2005): a földrajzi (geographical proximity) és a kapcsolati (ún. szervezett) közelséget (organized proximity);

a) A közelség fogalma a hagyományos fizikai, földrajzi szemléletben a távolság fogalmából vezethetỏ le. A távolság lényegében térbeli nem azonosságra, két egység (személyek, szervezetek, városok stb.) térbeli eltérésének mértékére utal, amely számszerüsített módon (km-ben, időegységben, költségben stb.) fejezhető ki. A távolság köznapi értelemben véve két hely közötti „legrövidebb út hosszát” jelöli (Nemes Nagy 2009, 219). Ennek alapján a közelség egyértelmủen kis távolságként, közvetlen szomszédságként értelmezhető. A térbeli koncentráció gazdaságosságát, a földrajzi közelség szerepét már 1890-ben megfogalmazta Marshall (Lengyel-Mozsár 2002), rávilágítva arra, hogy az ,iparági körzetek”-ben tömörülő cégek pozitív lokális extern hatásokat élveznek. A tudás túlcsordulás (knowledge spillover), a szakképzett munkaerō elérése és az inputok megosztása a termelési költségek csökkenéséhez vezetnek, mely előnyök egyértelmủen a földrajzi koncentráció révén érvényesülnek (Lengyel 2003; Varga 2006). Krugman (2000) is kiemeli, hogy szükség van a közelségre (ko-lokalizációra) az ipari tevékenységek folytatásához és a gazdasági szereplők közötti interakciók hatékony mủködéséhez.

A földrajzi közelség fogalmának pontositása végett megkülönböztetjük az állandó földrajzi közelséget, amely a szervezetek állandó fizikai közelsége, szomszédsága esetén áll fenn, és az ideiglenes földrajzi közelséget, amely a partnerek eseti, alkalmi személyes (face to face) találkozásai esetén jellemzö (Gallaud-Torre 2004; TorreRallet 2005).

b) A kapcsolati közelség alatt azt a képességet értjük, amely a szervezetek tagjai közötti interakciót segíti elő elsősorban a szervezeten belül, de a szervezeten kívül is. A kapcsolati közelség kétféle logikára támaszkodik. Abban az esetben, ha egy szervezet két tagja együttmüködik, a köztük lévő interakció hatékonyabbá válik, ha mindketten ugyanazokat a szervezetre jellemző magatartásformákat, rutinokat, szakmai nyelvezetet, explicit és implicit szabályokat követik. Ezt nevezik az odatartozás logikájának. Egy szervezet tagjai, szakemberei között így könnyebben kialakul a kapcsolat. A kapcsolati közelség másrészt a hasonlóság logikájára vezethető vissza, mivel a szervezet tagjai hasonló ismeretekkel, tudáselemekkel, szemlélettel, szokásokkal, meggyőződéssel rendelkeznek, ami ugyancsak megkönnyíti a tagok közötti együttmüködés kialakulását (könnyebben, mint egy szervezeten kívülivel). 
Több tanulmány is rámutat arra, hogy állandó földrajzi közelségre nincs mindig szükség az innovációs, tudásteremtő és $\mathrm{K}+\mathrm{F}$ folyamatokban. Az elmúlt időkben (az infokommunikációs technológiák révén) a személyek, információk, termékek mobilitása és szabadabb áramlásának lehetősége megnőtt, a munkamegosztás térbelisége átalakult. Ennek következtében nemcsak a földrajzi közelség mértéke, de az együttmüködések szorossága, kapcsolati közelségük is egyre nehezebben határozható meg objektív módon.

A tudásalapú gazdaságban a közelség gazdasági interakciókban betöltött szerepének vizsgálata során a közelség több dimenziója került elötérbe (Knoben-Oerlemans 2006). A földrajzi közelség mellett leggyakrabban négy közelség típus elkülönítésével találkozhatunk, amelyek mindannyian a partnerek közötti kapcsolati közelséget írják le. A közelség dimenziói külön-külön és együttesen is, egymás hatását erősitve segítik elő az innovációt, a tudás terjedését és átadását, a szervezetek együttmüködését.

A kapcsolati közelség tényezőit Boschma (2005) négy típusra, négy dimenzióra osztotta:

- A kognitív közelségben lévő vállalatok hasonló tudásbázisuknak, közös szakmai nyelvezetüknek köszönhetően új tudás, tapasztalatok, információk szerzésére és azok megosztására képesek.

- A szervezeti közelség a kapcsolatoknak ugyanazon térben való jelenlétére, a szervezeten belüli (intra-organizational), illetve szervezetek közötti (interorganizational) kapcsolatok szorosságára utal (Kirat-Lung 1999). Az erős szervezeti közelség teszi lehetővé a vállalatok kollektív tanulását, az új tudás létrehozásakor a bizonytalanság csökkentését.

- A társadalmi közelség az egyének, szervezetek közötti mikroszintủ kapcsolat társadalmi közegbe való beágyazódására utal, amely a bizalmi alapon mủködő személyes ismeretségeken, baráti, rokoni és egyéb személyes kötelékeken alapszik.

- Az intézményi közelség az azonos vagy hasonló, a szervezetek által megosztott és elfogadott formális (törvények, jogszabályok stb.) és informális (kulturális normák, értékek, szokások stb.) intézményi környezetben létrejött kapcsolatokat határozza meg.

A közelség típusainak mindegyike, még ha különböző mechanizmusok révén is, de valamihez való közelséget mérnek és hatással vannak a tudásátadás és -adaptálás folyamatának hatékonyságára, valamint együttmüködések, hálózatok és klaszterek kialakulására (Albino-Carbonara-Petruzzeli 2007). A felmérések igazolják, hogy a földrajzi és kapcsolati közelség dimenziói között ok-okozati viszony áll fenn, és legalább átmeneti, ideiglenes földrajzi közelségre van szükség ahhoz, hogy a kapcsolati közelség bármelyik típusa hatékonyan müködjön (Torre-Gilly 2000). 


\section{Regionális klaszterek és a közelség kapcsolata}

A közelség a vállalatok számára fontos versenyelőnyök forrását jelenti. A földrajzi közelség és a kapcsolati közelség együttes megvalósulása különböző szervezőđési, együttmúköđési formák kialakulását határozza meg, a közelség típusok eltérỏ mértékben való megvalósulásától függöen. Torre és Rallet (2005) tipizálását alapul véve Lagendijk és Lorentzen (2007) meghatározta a földrajzi és a kapcsolati közelség együttes elöfordulásának eseteit (1. táblázat).

A két eltérő közelség egymásra hatása négy alaptípust határoz meg. Az erős földrajzi és kapcsolati közelség együttesen két lehetséges esetben érvényesülhet $(1 \mathrm{a}, 1 \mathrm{~b})$ : egyrészt a termelési és innovációs tevékenységek térbeli koncentrációjában, jellemzően az innovatív klaszterekben, másrészt ideiglenes, de erős földrajzi közelséggel jellemezhetö, gyakori face to face kapcsolatok esetében. A gyenge földrajzi és szoros kapcsolati közelség (2) a földrajzilag szétszórtan elhelyezkeđő, de koordinált, kiépített kapcsolatrendszerrel rendelkező szervezeti egységekre (telephelyekre) vonatkozik. Az együttmüködéstől, interakciótól mentes, de földrajzilag koncentrált szervezetek esetén pedig (közlekedési) folyosókról (3), illetve agglomerációs elónyök indirekt hatásaiban részesülő térségekröl beszélhetünk. Az alapul vett modellt Lagendijk és Lorentzen (2007) egy negyedik esettel egészítette ki, figyelembe véve azt, amikor sem földrajzi, sem kapcsolati közelség nincs (4) és az innovatív együttmúködések is minimálisak. Ennek példájával föleg periférikus térségekben találkozhatunk.

\section{TÁBLÁZAT}

A földrajzi és kapcsolati közelség együttes elófordulásának esetei

(Intersection between Geographical and Organized Proximity)

\begin{tabular}{|c|c|c|}
\hline \multirow{2}{*}{$\begin{array}{l}\text { Földrajzi } \\
\text { közelség }\end{array}$} & \multicolumn{2}{|c|}{ Kapcsolati közelség } \\
\hline & Szoros (erös) & Laza (gyenge) \\
\hline $\begin{array}{c}\text { Erös } \\
\text { (közeli) }\end{array}$ & $\begin{array}{l}\text { 1a) Lokális innovatív (miliỏ) és } \\
\text { termelési rendszer (klaszter) } \\
\text { (1b) Ideiglenes földarajzi közel- } \\
\text { ség (ko-lokalizáció) (projektek, } \\
\text { találkozók) }\end{array}$ & $\begin{array}{l}\text { 3) Azonos földrajzi elhelyez- } \\
\text { kedés, szomszédság közvetlen } \\
\text { (direkt) interakció nélkül } \\
\text { (közlekedési folyosó, agglo- } \\
\text { meráció) }\end{array}$ \\
\hline $\begin{array}{l}\text { Gyenge } \\
\text { (távoli) }\end{array}$ & $\begin{array}{l}\text { 2) Nem helyi együttmúködések } \\
\text { (értékláncok, több telephelyes } \\
\text { szervezetek, IKT-t alkalmazó } \\
\text { együittmüködések) }\end{array}$ & $\begin{array}{l}\text { 4) Elszigetelt tevékenységek } \\
\text { (rurális, periférikus térségek- } \\
\text { ben) }\end{array}$ \\
\hline
\end{tabular}

Forrás: Lagendijk és Lorentzen $(2007,461)$ alapján saját szerkesztés.

Az erős fizikai közelség, a földrajzi koncentráció és a szoros kapcsolati közelség együttes jelenlétének leginkább szembetünő esetei a regionális klaszterek. A regionális klaszterek fogalmának megalkotása Michael E. Porter nevéhez füződik, aki 
vizsgálatai során a vállalati szintủ versenyelönyökre és azok forrásaira fektetett hangsúlyt. Megfogalmazta, hogy „a klaszter egy adott iparág földrajzilag közel elhelyezkedó vállalatainak, intézményeinek, támogató és kapcsolódó (kiegészitö) iparágainak csoportja" (Porter 2000, 254). Kiemeli, hogy a klaszter nem csak a földrajzilag közel elhelyezkedő vállalatok szerveződése, hanem azok technológiai, tudáscsere érdekében létrejött szoros, innovatív kapcsolatrendszere is, amelynek alapját egyértelmúen a szoros kapcsolati közelség határozza meg. A vállalatok számára a térbeli sürüsödésük révén lehetővé válnak a pozitív externáliákból eredö költségelőnyök is (Lengyel-Mozsár 2002). Ilyen elöny a vállalatok speciális oktatási intézményekhez, szolgáltatásokhoz, infrastruktúrához való hozzáférése és az alvállalkozókhoz, tanácsadókhoz való közelsége és annak lehetősége, hogy alacsonyabb egységköltségen, alacsonyabb szállitási és tranzakciós költségek mellett szerezzék be inputjaikat (Lengyel 2001).

A tudásalapú gazdaság fejlődését meghatározó tényezők között kiemelt jelentöséggel bír a földrajzi és a kapcsolati közelség révén megvalósuló tudás terjedés, amely az innovációra és így a tudásalapú szerveződések fejlődésére gyakorol jelentős hatást. Nem elég a tudás térbeli kiterjedtségének és egy adott terület innovációs kapacitásának feltárása, hanem szükség van azon csatornák meghatározására is, amelyeken keresztül az innováció a térben létrejön és terjed. Ennek vizsgálatára különböztette meg Capello és Faggian (2005) a földrajzi, fizikai közelséget a kapcsolati közelségtỏl és az általuk definiált kapcsolati tértöl (relational space) (1. ábra).

A fizikai közelség lehetővé teszi a gazdasági szereplők közötti kapcsolatok kialakulását, és növeli a tudás, az információ és a legjobb gyakorlatok cseréjének valószínüségét. A földrajzi közelség alapvetően a tudás túlcsordulásához szükséges agglomerációs (lokalizációs és urbanizációs) elönyöket, valamint a tudásteremtő szervezetek közelségét jelenti. A kapcsolati tér ezzel szemben minden olyan gazdasági, intézményi szereplö közötti kapcsolati formát magában foglalja, amely a partnerek kapcsolati közelsége, közös értékei, együttmüködési készsége, összetartozás érzése révén jött létre. Ez pedig hatással van a kapcsolati tőke megerősödésére, az explicit és implicit együttmüködések kialakulására, így a tudás terjedésére is.

A földrajzi és a kapcsolati tér megközelítések hasonló módon és egy időben járulnak hozzá a tudás terjedéséhez és átadásához, az innováció megvalósulásához és olyan innovatív kapcsolatrendszerek kialakulásához, amelyek a regionális klaszterek alapját is jelentik (Grosz-Rechnitzer 2005). Tény, hogy a földrajzi közelség pozitív befolyással van a vállalatok, kutatóintézetek kapcsolatára, innovációs teljesítményére, de a kapcsolati tér vizsgálata nélkül nem határozható meg, hogy ez a befolyás hogyan keletkezik és milyen mértékben. A kapcsolati tér meghatározó az interaktív, kollektív tanulás folyamatában, a tapasztalat és a tudás cseréjében és így olyan tudásalapú szerveződések fejlödésében, mint a klaszterek. 
Vas Zsófia : Közelség és regionális klaszterek: A szoftveripar Szegeden.

Tér és Társadalom 23. évf. 2009/3. 127-145. p.

TÉT XXIII. évf. 2009 @ 3

Gyors ténykép

1. ÁBRA

A földrajzi és kapcsolati tér szerepe az innováció és a klaszterek létrejöttében (Role of Physical and Relational Space in Innovation and in Cluster Forming)

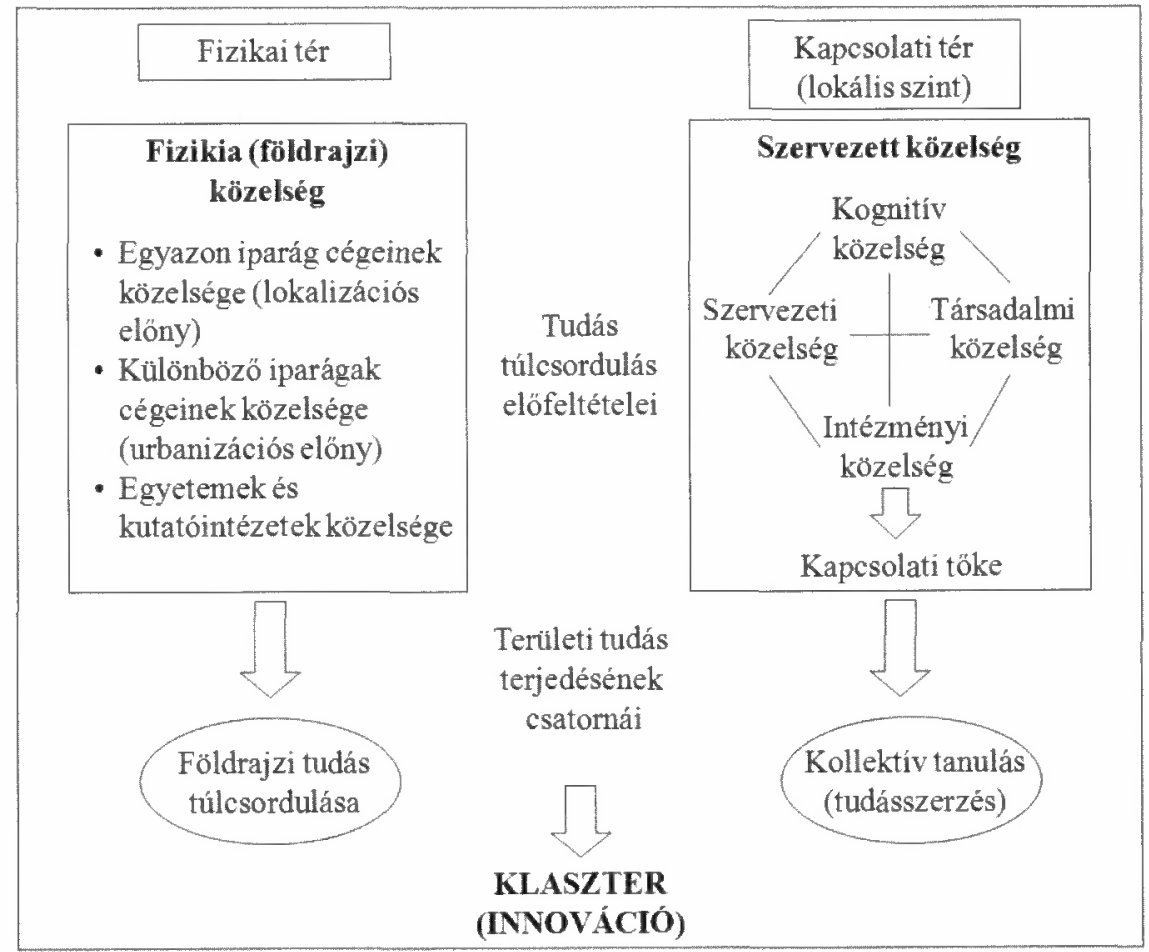

Forrás: Capello-Faggian (2005) ábrájának módosításával saját szerkesztés.

\section{Szoftveripari klaszterek nemzetközi tapasztalatai}

Az Európai Unió által kiemelten támogatott IT a tudásalapú gazdaság egyik fontos bázisa. Vizsgálata azért érdekes, mert a hagyományos iparági tevékenységekhez (pl. élelmiszeriparhoz, autóiparhoz) képest a szoftveripari klaszterek sajátosak a termelési és fejlesztési folyamatokban, a vállalati kapcsolatrendszerekben. Az információs technológiának, így a szoftveripari szolgáltatásokat nyújtó iparágaknak kulcsszerepük van az információs társadalom fejlödésében (amely fejlesztésének szükségességét az Európai Bizottság is elismerte új stratégiai keretprogramjában, az „Európai Információs Társadalom 2010" által), mivel szinte minden szektorban elengedhetetlenek az üzleti tevékenységek folytatásához (termék- és szolgáltatásfejlesztés, marketing, értékesítés területén) (ISM 2006).

A szoftveripari vállalatokat intenzív kutatói tevékenység jellemzi, és az IKT lehetővé teszi, hogy tevékenységeiket partnereik nagy földrajzi távolsága ellenére is hatékonyan menedzseljék és koordinálják. A szoftveripari termékek sajátossága, hogy alapvetően szellemi termékek (szoftverek, távszolgáltatások), amelyek szállí- 
tása a modern infokommunikációs technológiák révén a fogyasztókhoz, üzleti partnerekhez gyorsan és közvetlenül megoldható. A szoftveriparban kialakult klaszterek az iparági szerveződések egyedi példái. Nagyon ritkán lehet kizárólag szoftveripari klaszterrel találkozni, mivel általában egy nagyobb, jellemzően információs és kommunikációs technológiai klaszterbe ágyazottan jönnek létre, vagy egy high-tech klaszterben müködnek, háttérszolgáltatásokat nyújtva olyan iparágak számára, mint a gyógyszer-, vegyipar, biotechnológia stb.

Az IT-iparágban számos fejlett klaszter múködik úgy, mint a müncheni IT klaszter, vagy a cambridge-i IT szuperklaszter. De egyre több olyan klaszterrel és klaszter kezdeményezéssel is találkozhatunk, amelyek Szegedhez hasonló földrajzi, társadalmi, gazdasági feltételekkel rendelkeznek (pl. Oulu), avagy kevésbé fejlett régiókban mủködnek (Cork). Söt, IT klaszterek megfigyelhető́k az EU új tagállamaiban is.

Az írországi Cork-ban található szoftveripar sikerének kiinduló feltételeit kedvező infrastrukturális helyzete, alacsony költségfeltételei adták, amelyek nagyban hozzájárultak a fejlődés kulcsához, a külföldi tőkebefektetések odavonzásához (OECD 2000). A helyi vállalati szféra fejlődésében fontos szerepe volt a kormányzati szervezetek és állami fejlesztési ügynökségek (Enterprise Ireland) közelségének, amelyek tudatosan irányították Cork városát afelé, hogy innovatív tevékenységek jövőbeli központjává váljon. A városban létrehozott „tudás zóna” megfelelő környezetet teremt a partnerviszonyok kiépülésére. A zóna lehetőséget biztosít a cégek számára, hogy a város tuđásközpontjának közelében telepedjenek le, elősegítve a kollektív tanulást, a szoros kapcsolatokon, kapcsolati közelségen alapuló együttmüköđéseket, kutatásokat, valamint a vállalatok és az akadémiai szféra tagjai közötti innovációs tevékenységeket és az ötletek szabad áramlását (CCC 2005). A szoftveriparban érintett szereplök számára az információhoz, kapcsolatokhoz való hozzájutást biztosítják a konferenciák, rendezvények, üzleti ebédek megszervezése, amelyek az erős (ideiglenes) földrajzi közelséget kihasználva a kapcsolati közelséget erősítik.

Oulu (Finnország) a világ olyan vezető innovatív klasztereinek egyike, melynek kialakulása és fejlődése számtalan egymásra épülő tényező sorozatának (az 1960-as évek óta meglévő egyetemi háttérnek, a széles, szakképzett munkaeröbázis közelségének stb.) az eredménye (Congress Oulu 2006). Az oulu-i szoftveripar hagyományos ipari tevékenységekhez viszonyított gyors fejlődése azonban nem ment volna végbe a Nokia letelepülése nélkül (ISM 2006). Oulu és vonzáskörzetének fejlődésében a đecentralizált, a közelség révén a helyi igényeket felismerő regionális fejlesztési ủgynökségek aktív szerepvállalása, továbbá az információs és tudásközvetítöként szolgáló szakértői központ kiépítése is meghatározóvá vált, amely a földrajzi és kapcsolati közelséget kihasználva igyekszik a régió high-tech iparágbeli cégeinek, oktatási és kutatóintézeteinek együttmüködését ösztönözni.

$\mathrm{Az}$ EU-hoz újonnan csatlakozott országokban a szoftveripari együttmüködések tudatos fejlesztése az elmúlt évtizedben kezdődött, alapvetően a befektetéseknek kedvezö üzleti környezet kiépítésével és költségelőnyök nyújtásával. Ostravában (Csehországban) megteremtették annak feltételeit, hogy a vállalatok, a befektetők és az egyetem közötti közvetlen kapcsolatok kiépüljenek a közelség nyújtotta elönyök 
tudatos kihasználásával: ipari területeket, technológia parkot és innovációs központot épitettek ki (CSKI 2002). Tudatos lépéseket tesznek a régión kívülröl érkező munkaerő (és egyetemi hallgatók), vállalatok, innovatív tevékenységek odacsábítására. Észtországban, Tartu IT klaszterének folyamatos fejlődését exporttevékenységének, külföldi piacokon való megjelenésének köszönheti. Legnagyobb kereskedelmi partnereinek, finnországi és svédországi IT vállalatoknak biztosított intenzív beszállítói tevékenysége lehetőséget ad arra, hogy az ottani klaszterekbe beágyazottan müködjön, a legfejlettebb technológiákat adaptálja, és közös termékfejlesztéseket, kutatásokat hajtson végre a kapcsolati közelség révén (Tartu Region 2007).

Az EU tagországokban létrejött és vizsgált klaszterek és kezdeményezések mindegyike adaptálható ötletekkel szolgálhat egy olyan típusú város szoftveriparának fejlesztésében is, mint Szeged. Szeged szoftveriparának fejlỏdését elsősorban vállalati köre és egyetemi háttere teszi lehetövé. A külföldi esetek mindegyikében látható, hogy a fejlỏdés egyik kulcsa a megfelelő tudásbázis és munkaerőbázis elérhetősége, melyek megléte Szegeden is biztosított az egyetem által, oktatói és kutatói bázisa révén. Ez lehetövé teszi a közvetlen egyetemi-vállalati kapcsolatok kiépülését, és egymáshoz való közelségüket kihasználva az üzleti tevékenységek és fejlesztések végrehajtását. Szeged határ menti helyzete miatt a határon átnyúló kapcsolatok is fontos elönyöket jelenthetnek (Rechnitzer-Smahó 2007).

\section{A szoftveripar földrajzi koncentrációja Szegeden}

Szeged városában és vonzáskörzetében nincs olyan vezető ágazat vagy versenyképes nagyvállalati kör, amelyhez az oktatási és kutatási célok kizárólag igazodnának (Lengyel 2006). Emiatt is indokolt a térség szoftveriparában érintett kis- és közepes vállalatok kapcsolatrendszerének felmérése, feltárva a közelségtípusok jelenlétét és szükségességét, továbbá a klaszteresedés lehetőségét. A klaszteresedési lehetőségek elemzésének első lépését az iparág országon és régión belüli súlyának feltérképezése és igazolása, majd földrajzi koncentrációjából eredő előnyök vizsgálata jelentheti, és annak feltárása, hogy a vállalati kapcsolatok a közelség mely tényezöire vezethetók vissza, megalapozva egy szoftveripari klaszter kialakulását.

A térségben a szoftveripar húzóágazati mivoltát a város adottságai is alátámasztják. Fejlesztési pólusként a város olyan tudásbázissal rendelkezik, amely egyetemi hátterének, oktatói és kutatói tevékenységének, az egyetemi hallgatók magas számának (közel 30 ezer hallgató) és színvonalas képzési rendszerének, többek között a kiépült informatikai képzésnek és az évente közel 300-500 informatikai jellegü diplomásnak köszönheti (Lengyel 2006). Ez biztosítja a munkaeröbázis folyamatos újratermelődését, és a szakképzett fiatal munkaerö vállalkozói hajlamának növelésével az új vállalkozások létrejöttét. Szegeden a szoftveripari vállalatok köre kiépült, és az első lépések is megszülettek egy hatékonyabb együttmüködési forma (klaszter) kialakulásának érdekében. 
A szoftveripar olyan szellemi tevékenységekböl áll, amelyek új tudás létrejöttét, nagyobb hozzáadott értéket biztosítanak, és amelyek generálják további gazdasági tevékenységek fejlődését. Ezért a szoftveriparban (az adatok elérhetősége miatt, a TEÁOR 2003 alapján) csak egy alágazatot, a 'szoftver-szaktanácsadás, -ellátás' (TEÁOR 72.2.), illetve azon belül is két szakágazatot, a szoftverkiadást (72.21) és egyéb szoftver-szaktanácsadást, -ellátást (72.22) tekintünk szoftveriparnak. Az így definiált szoftveripar magában foglalja a szoftvertermékek kifejlesztését, megtervezését, előállítását, kiadását és az ehhez szorosan kapcsolódó tanácsadói tevékenységet folytató (Szegeden közel 200) vállalatot.

Cél a szoftveripar földrajzi koncentrációjának és húzóágazatként való jelenlétének igazolása Szegeden és vonzáskörzetében. „Húzóágazatnak akkor tekinthetjük gazdasági szereplók egy csoportját, ha a térség gazdaságában meghatározó súllyal rendelkezik, valamint kellö növekedést mutat" (Patik-Deák 2005, 143). Az ágazat súlyát a hozzáadott érték, a foglalkoztatottak és a vállalkozások száma alapján határozhatjuk meg. A hozzáadott érték nehezen vizsgálható, de a foglalkoztatottság és a vállalkozások koncentrációjának mértéke statisztikai adatok alapján pontosan meghatározható a leggyakrabban alkalmazott mutató, az LQ index (lokációs hányados) által (2. táblázat).

A szükebb értelemben vett szoftveripari klaszterhez szükséges a kritikus tömeg és specializáció, ha a szegedi szoftveripar koncentrációja nemcsak a régión belül, hanem országos szinten is bebizonyosodik (Patik-Deák 2005). Az LQ indexet két megközelítésben nézzük: egyrészt a Magyarországon található összes szoftveripari céget, másrészt csak a 'vidéki Magyarország' szoftveripari vállalatainak számát vesszük figyelembe, utóbbi esetben elhagyva a Budapesten található több mint 5000 vállalatot. Szegedet a nagyobb vidéki városok, a pólusvárosok értékeivel hasonlítjuk össze, Székesfehérvár kivételével (ahol a Közép-Dunántúli Regionális Informatikai Klaszter található).

\section{TÁBLÁZAT}

Vállalkozási és foglalkoztatási $L Q$ értékek (Value of LQ for Entreprises and Employment)

\begin{tabular}{lcccc}
\hline & \multicolumn{2}{c}{ Vállalkozási $L Q$} & \multicolumn{2}{c}{ Foglalkoztatási LQ } \\
\cline { 2 - 5 } & Magyarország & $\begin{array}{c}\text { Vidéki } \\
\text { Magyar- } \\
\text { ország }\end{array}$ & Magyarország & $\begin{array}{c}\text { Vidéki } \\
\text { Magyar- } \\
\text { ország }\end{array}$ \\
\hline Budapest & 1,390 & & 2,171 & \\
Szeged & 0,944 & 1,256 & 1,119 & 2,867 \\
Györ & 0,829 & 1,104 & 0,431 & 1,105 \\
Pécs & 1,016 & 1,352 & 0,557 & 1,429 \\
Miskolc & 0,617 & 0,822 & 0,689 & 1,767 \\
Debrecen & 0,858 & 1,142 & 0,681 & 1,744 \\
Székesfehérvár & 1,173 & 1,561 & 0,898 & 2,300 \\
\hline
\end{tabular}

Forrás: Opter Cégtár és a KSH Cégkódtár adatai alapján saját számítás. 
A statisztikai adatok alapján a klaszterfeltérképezés igazolta a szoftveripari vállalkozások és foglalkoztatottak Szegeden és vonzáskörzetében lévő relatív koncentrációját. A szoftveripari vállalkozások (vállalkozási LQ) országon belüli aránya csak Budapesten és Székesfehérváron meghatározó. A vidéki Magyarországon, Székesfehérvárt és Pécset követóen azonban Szegeden is magas a vállalkozások koncentrációja, 1-nél nagyobb LQ értékek elérésével. A szoftveriparban foglalkoztatottak száma (foglalkoztatási LQ) alapján ennél kiemelkedőbb értékekhez juthatunk. Országos szinten Szegedet (több mint 550 fős foglalkoztatottal) nem érdemes Budapesthez (közel 19 ezer fö) viszonyítani, de a vidéki nagyvárosokhoz képest dominanciája bizonyitható. A 2-nél is nagyobb foglalkoztatási LQ értéket (amelyet az European Cluster Observatory is határértékként alkalmaz) Szeged mellett csak Székesfehérvár éri el. Mindezek alapján a foglalkoztatottak számában is igazolható a szegedi szoftveripar relativ koncentrációja Magyarországon.

A Dél-alföldi régióban a szoftveripari vállalatok és foglalkoztatottak száma nem vethető össze a hagyományos húzóágazatokban müködő vállalatok és foglalkoztatottak számával ( $\mathrm{pl}$. az élelmiszeriparral). Az LQ kiszámított értékei alapján azonban kijelenthető, hogy önmagában a szoftveripari vállalkozások szegedi koncentrációja kiemelkedő az országos átlaghoz, más vidéki városok értékeihez képest.

\section{Szoftveripari vállalatok földrajzi és kapcsolati közelsége}

A szoftveripari vállalatok közötti kapcsolati közelség jelenlétének és erősségének vizsgálatára kérdőíves felmérés ad lehetőséget. A kérdőív összeállitása az European Cluster Observatory klaszterfeltérképezési tanulmányai és a Harvard Business School által, Michael Porter vezetésével folytatott regionális innovációs klaszterek felmérésére irányuló kérdöív alapján történt. A közelség meglétére és intenzitására vonatkozó kérdések a közelség szakirodalmának tanulmányozása során merültek fel és kerültek összegyüjtésre (3. táblázat).

A kérdöives felmérés alanyai a szegedi kistérségben lévő vállalatok köre. A Szegeden és vonzáskörzetében székhellyel vagy telephellyel rendelkező, cégforma szerint ( $\mathrm{kft}$. és rt.) megkülönböztetett vállalatok állnak a felmérés középpontjában. A közelség dimenzióit feltáró kérdések öt kérdéscsoportban kaptak helyet, ahol a kérdések mindegyike olyan tényezők meglétére, vállalatok általi megitélésére és intenzitásának mérésére fókuszál, amelyek rámutatnak egy potenciális szoftveripari klaszter kiépülésének lehetőségére.

A kérdőíves felmérés során a szủkebb szoftveripar 91 vállalkozásának cégvezetöit kerestük meg. A vállalkozások közül 18 nem volt elérhető, és két telephelyröl kiderült, hogy csak formálisan léteznek, valójában semmilyen funkciót nem töltenek be. A megkeresett 74 vállalattól végül 31 kitöltött kérdőiv érkezett vissza, mely eredményt nem tekinthetjük reprezentatívnak, de figyelemre méltó, hogy a vállalati kör $34 \%$-ának véleményét tükrözi. Úgy véljük, ez alapján megalapozott következtetések levonására nyílik lehetőség. 
Vas Zsófia : Közelség és regionális klaszterek: A szoftveripar Szegeden.

Tér és Társadalom 23. évf. 2009/3. 127-145. p.

\section{TÁBLÁZAT}

A közelség jelenlétének és intenzitásának mérésére szolgáló tényezők a kérdőivben (Factors Measuring the Presence and Intensity of Proximity in the Questionnarie)

Mérési tényezők

- lokális, regionális, nemzeti és nemzetközi partneri kapcsolatok jelenléte és mértéke (fogyasztók, beszállítók, üzleti partnerek, egyetem, kutatóintézet, fejlesztési ügynökség, versenytárs, közigazgatási szerv stb.)

- tényező feltételek (szakember, oktató-, kutatóintézet, technológia, üzleti szolgáltatások stb.) jelenléte és közelségéböl eredő elönyök hasznosításának mértéke

- tényező feltételek (szakmai és személyes kapcsolatrendszer, információ, munkaerő, pénzügyi forrás stb.) lokális hiánya és ennek hatása

- helyi iparágak igényeit kielégítő kiegészítő termékek gyártása és mértéke

- foglalkoztatottak azonos szakmai végzettsége, közös tanulmányok, azonos egyetemi háttér, régi munkakapcsolatok aránya

- $\mathrm{K}+\mathrm{F}$ és innovációs tevékenységek folytatásának mértéke és gyakorisága

- fejlesztési célú együttmüködések aránya

- szakmai klubokban, fórumokon, rendezvényeken stb. való részvétel

- szakmai, üzleti kapcsolati formák mértéke a szervezeten belül és szervezetek között (pályázatok, projektek, konzorciumok stb.)

- személyes, informális kapcsolati formák mértéke a szervezeten belül és szervezetek között (családi, baráti stb. kapcsolatok hatása a szervezet müködésére)

- társadalmi háttér vállalati müködésben betöltött szerepe és értéke

- családi, rokoni, baráti és egyéb személyes kapcsolatok megítélése és hatása:

- vállalati piaci pozíció elérésében, megtartásában

- információ és tudás szerzésében

- vállalatok müködését befolyásoló formális (törvények, rendeletek, jogszabályok) és informális (kulturális normák, szokások, vállalati rutinok) intézményi keret elemeinek fontossága és érzékelt hatása

- a térség gazdaság- és vállalkozásfejlesztési gyakorlatának elemei és hatása

Forrás: Saját szerkesztés. 
Magyarországon a szoftveriparban sajátos módon mutatkozik meg a földrajzi közelség szerepe. A vállalatok partneri kapcsolatokra vonatkozói adatai (a kapcsolatok mértéke, a kapcsolattartás intenzitása) megerősítik azt az általánosan ismert hazai adottságot, hogy Budapest túlsúlyos szereppel bír. A vállalatok több mint 70\%-ánál találhatók kiterjedt fogyasztói és ügyfélkapcsolatok helyben és a fóvárosban egyaránt (2. ábra). A Szeged-Budapest közötti földrajzi távolság nem akadályozza az együttmüködések kialakulását, amibỏl arra következtethetünk, hogy az egyének közötti erős kapcsolati közelség megléte a kapcsolatépítés forrása. A vállalatok 61\%-a müködik együtt Budapesten müködő versenytársaival, ami magasabb, mint Szegeden. A Dél-alföldi régióban és a régión kívül Magyarországon a partnerkapcsolatok ugyancsak jelentősek, de számuk kisebb. Mindebből azt a következtetést vonhatjuk le, hogy a szoftvertermékek és tevékenységek piacának határai tágak, köszönhetően az infokommunikációs technológiák alkalmazhatóságának is. Ezt támasztja alá az is, hogy a megkérdezettek a földrajzi közelséget egy ötfokú skálán (ahol az 1 nem fontos, 5 nagyon fontos) közepesen fontos tényezőként értékelték (2,71 átlagérték). A szoftveripari vállalatok számára a földrajzi közelség jelentős ugyan a partnerség kiépitésében, de egy adott cél, jellemzően egy megrendelés teljesítésének érdekében hiánya nem akadályozza az együttműködés létrejöttét.

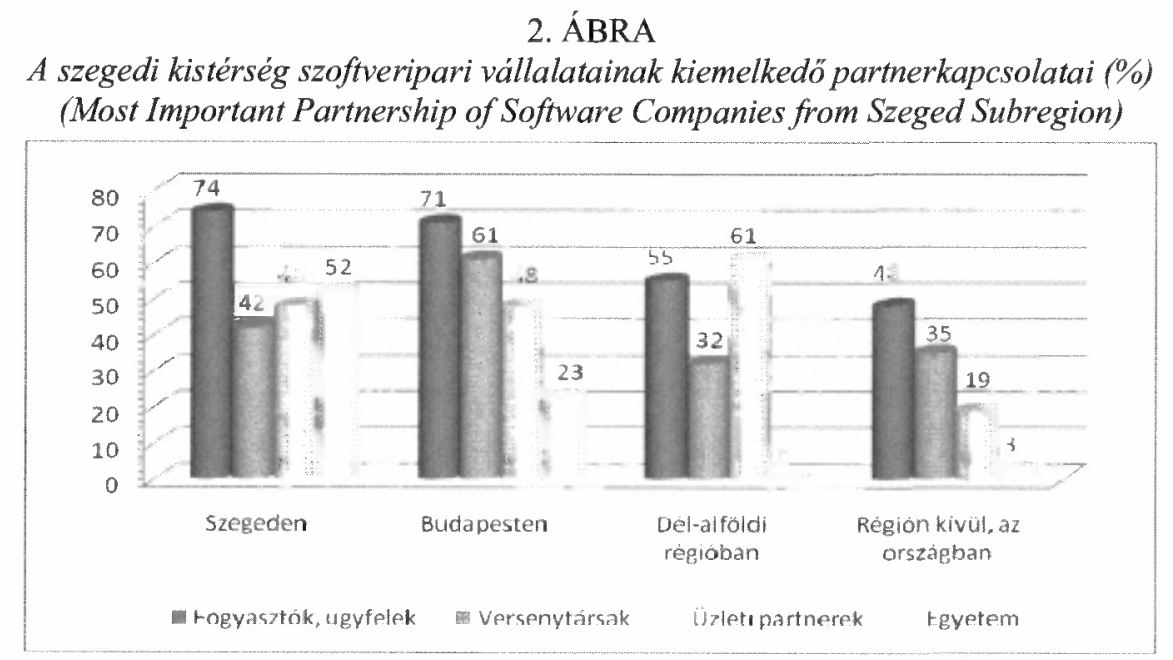

Forrás: Kérdỏív alapján saját szerkesztés.

A felmérés igazolja, hogy a szoftveripari tevékenységek folytatásához elengedhetetlen a (legalább ideiglenes) földrajzi közelség megléte Szegeden és vonzáskörzetében is - kiemelten az oktató és továbbképző intézetek, az innovatív emberek, ötletek, technológiák elérésében és a költségek csökkentésében. A földrajzi közelség az innovatív együttműködések, termékfejlesztések folyamatának egyes fázisaiban, így a projektek megtervezése, a kezdeti tárgyalások, a fejlesztési igény kialakítása, a szakmai tanácsadás során kiemelten fontos. 
Szegeden a szoftveriparban erösek a helyi kapcsolatok, amelyek a térség tudásszigetként való értékelését támasztják alá. A szegedi vállalatok esetében az egyetem közelsége kiemelt hatással bír. A vállalatok több mint fele tart fenn rendszeres kapcsolatot egyetemmel, kutatóintézettel, jellemzően a Szegedi Tudományegyetemmel, de kisebb mértékben (a vállalatok 23\%-a) a Budapesti Müszaki és Gazdaságtudományi Egyetemmel és a Magyar Tudományos Akadémia kutatóintézeteivel.

A Szegedi Tudományegyetem hatása számos vonatkozásban érvényesül. A megkérdezett vállalatok ötfokú skálán értékelték az egyes tényezők befolyását a vállalatok innovativitására ( 1 nincs hatással, 5 nagy hatással van) (3. ábra). Az egyetemet a vállalatok az innovációs tevékenységre legnagyobb hatással rendelkezőként értékelték, a hatékony munkaerő és az információs hálózatok tényezőit követően. Ezt támasztja alá, hogy a szegedi szoftveripar cégvezetöinek $78 \%$-a, foglalkoztatottainak többsége (néhol 50\%-a, legtöbb esetben több mint 75\%-a) a Szegedi Tudományegyetem Természettudományi és Informatikai Karán végzett. Az egyetem, mint közvetítő közeg és a tudásfolyamatok meghatározó szereplője nagymértékben hozzájárul ahhoz, hogy a szegedi szoftveripari vállalatok kapcsolati közelségbe kerüljenek egymással.

\section{3. ÁBRA}

Szoftveripari vállalatok innovativitását befolyásoló legfontosabb tényezök (Most Important Factors Influencing the Innovativiness of the Software Companies)

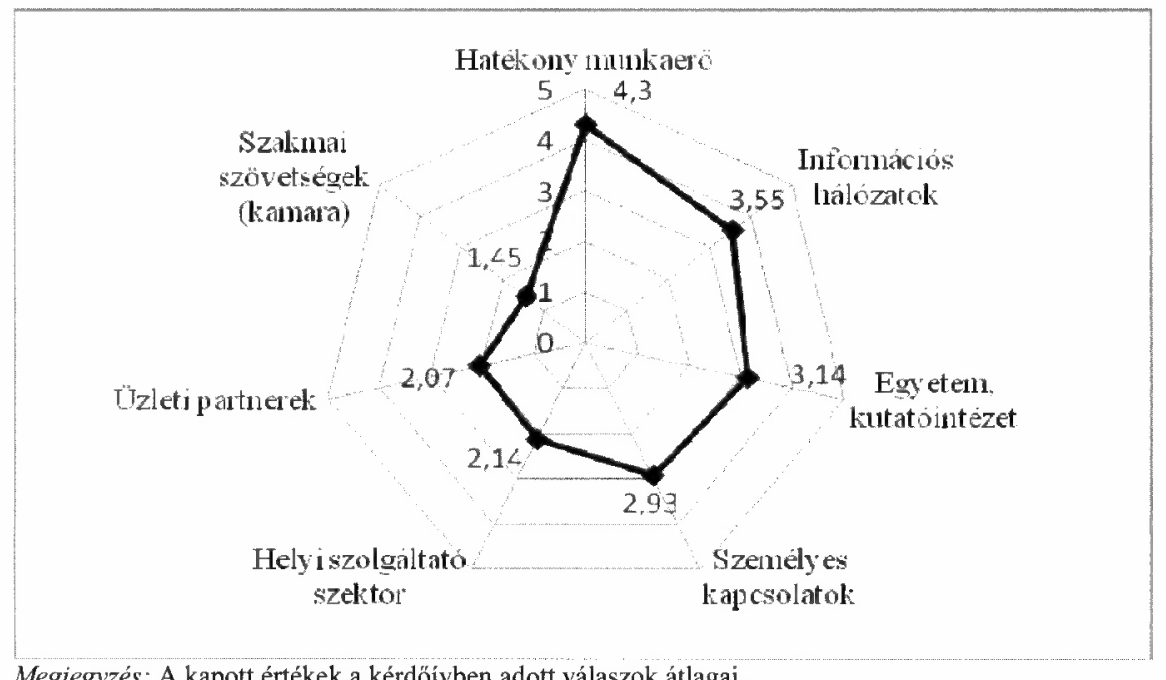

Megjegyzés: A kapott értékek a kérdőívben adott válaszok átlagai.

Forrás: Kérdőív alapján saját szerkesztés.

A kapcsolati közelség innovációs kapcsolatok kialakításában betöltött szerepe és jelenléte alátámasztást nyert azáltal, hogy a vállalatok közel azonos tudásbázissal rendelkeznek, kognitív közelségben vannak. Amellett, hogy a cégvezetők és alkalmazottak többsége közös egyetemi háttérrel rendelkezik, $75 \%$-uk vett részt a közelmúltban valamilyen szakmai konferencián, továbbképzésen. Az üzleti alapú 
együttműködések közül kiemelkedik a vállalatok $90 \%$-ának közös pályázatokon való részvétele, a közös kutatási eredmények kidolgozása és hasznosítása, valamint a $\mathrm{K}+\mathrm{F}$ projekteken és konzorciumokon való részvétel - még ha eseti jelleggel is -, amelyek nem jöhetnének létre bizonyos tudás azonosságok és a közelség más dimenziói nélkül.

A szoftveripari vállalatokat intenziv innovációs tevékenység jellemzi, 65\%-uk saját kutatás-fejlesztést végez. Az elmúlt három évben a vállalatok $87 \%$-a hajtott végre valamilyen innovációt, jellemzöen termék- $(65 \%)$ és technológiafejlesztést. 45\%-uk jelent meg új piacon termékeivel, és ami érdekes, hogy csak $22 \%$-uk vásárolta az alkalmazott technológiát, a többiek maguk fejlesztették.

Szegeden a vállalatok vezetői és alkalmazottai közötti személyes, informális kapcsolatok központi jelentőségúek. A vizsgált vállalatok a müködés, a piaci pozíció elérésének szempontjából az ötletek, tapasztalatok megosztásánál, a tudás és információ megszerzése, átadása során ezeket a kapcsolatokat nagyon fontosnak ítélik, és hiányukat olyan tényezönek tartják, amelyek befolyásolni tudják a vállalat fejlődését. Valamennyi vállalat igénybe veszi az informális kapcsolati formákat, amelyek a szervezeti közelség révén létrejöttek, és sokszor a korábbi munkakapcsolatokra, közös egyetemi évekre vezethetők vissza.

A szegedi szoftveripari vállalatok társadalmi háttere és a köztük lévő szoros társadalmi közelség egyértelmű. A fennálló személyes kapcsolatrendszer kiterjedtsége azonos társadalmi kontextusba ágyazottságra utal. Ez egyrészt megkönnyíti a kooperációt, az információk és a tudás áramlását, másrészt az iparág fejlődését tekintve hátrányt jelenthet, ha a személyes kapcsolatrendszerrel nem vagy kevésbé rendelkező vállalatok mindezt zárt társadalmi közegként érzékelik, és ủj ötleteikkel nem képesek a folyamatok szerves részévé válni. Ez hosszabb távon akár az innovációs teljesítmény növekedésének komoly gátjává is válhat. Igaz, jelenleg a vizsgált vállalatokat aktív innovatív tevékenység jellemzi.

A vállalatok közötti kapcsolati közelség erősségét a makroszintü, formális és informális intézményi háttér is meghatározza. A vállalatok azonos befolyásoló tényezőkkel rendelkeznek, ugyanazon törvények, jogszabályok vonatkoznak rájuk, és ugyanazon kulturális értékek és normák által meghatározottak. Mégha a vállalatok erős intézményi közelségben is vannak, az intézményi háttér hatásait a vállalatok eltérő módon értékelik. A kormányzat feladata a vállalatok és szerveződéseik elótt álló piaci korlátok megszüntetésében, a piaci verseny szabályozásában és az inputok (infrastruktúra, technológia stb.) hozzáférésében van. A vállalatok azonban elégedetlenségüket fejezték ki (ötfokú skálán 1 nem elégedett, 5 nagyon elégedett) a helyi önkormányzat $(1,93)$ és a központi közigazgatási szervek $(1,82)$ szerepvállalásával, a jogi szabályozás követhetőségével $(2,03)$, az adminisztrációs követelményekkel $(1,57)$ és a kis- és közepes vállalkozások érdekképviseletével $(1,72)$ kapcsolatban.

A vállalatok véleménye szerint Szeged város gazdaság- és vállalkozásfejlesztési gyakorlata csak kis mértékben segíti elő a klaszterek, hálózatok, együttmúködések kialakulását, a régión kívüli piacra való kilépést, cégalapítást, üzlet- és piacfejlesztést (4. ábra). 
Vas Zsófia : Közelség és regionális klaszterek: A szoftveripar Szegeden.

Tér és Társadalom 23. évf. 2009/3. 127-145. p.

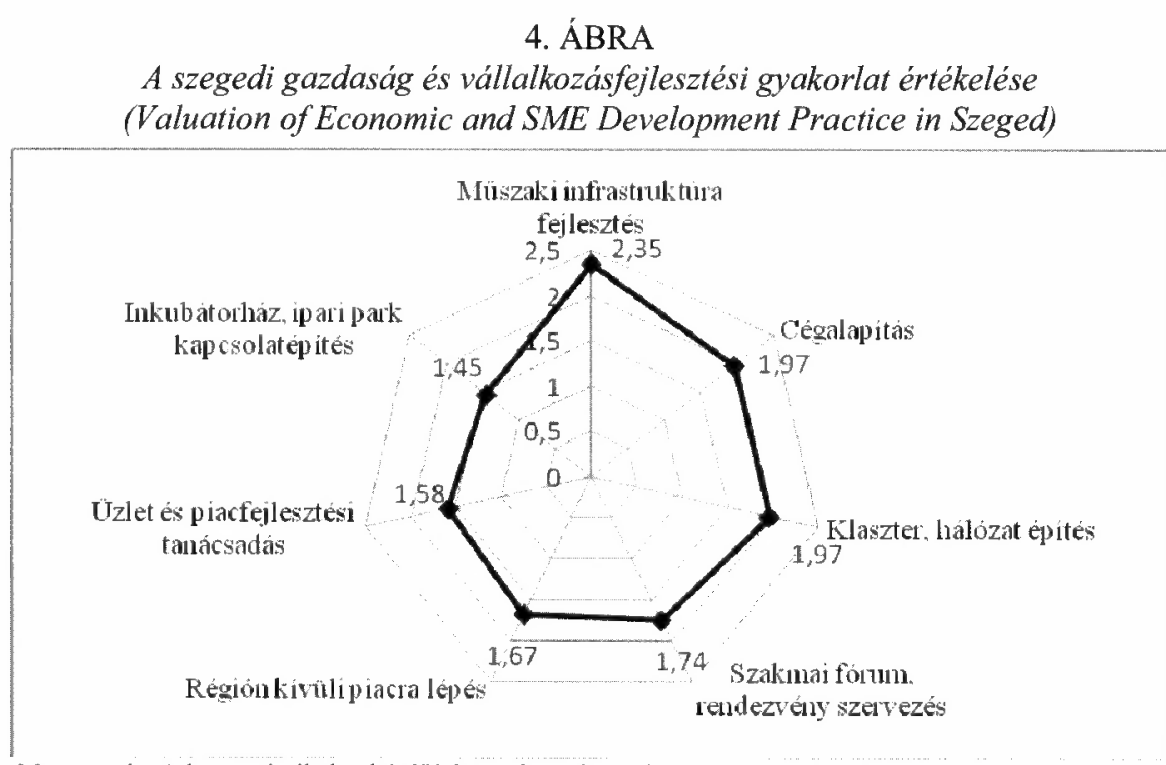

Megjegyzés: A kapott értékek a kérdőivben adott válaszok átlagai.

Forrás: Saját szerkesztés.

Ezen tapasztalatok visszavezethetőek arra, hogy hazánkban a klaszterfejlesztési célkitüzések megfogalmazása csak rövid múltra tekint vissza, és jelenleg a tudatos klaszterfejlesztési politika még kevésbé képezi szerves részét a központi gazdaságfejlesztési politikának (Grosz 2006). A megfelelö klaszterorientált programok kiépitésével, a megfelelő szerepvállalással mindezen tényezők kiküszöbölhetök, a vállalatok és partnereik közötti intézményi közelség még erősebbé válhat.

A kapcsolati közelség egyes elemeinek részletes vizsgálatát követően bebizonyosodott, hogy a szoftveriparban Szegeden és vonzáskörzetében megvalósul az innováció és a tudásfolyamatok magas színvonalon tartása, mely a kapcsolati közelség megléte nélkül nem valósulna meg. A kutatásból kiderült, hogy a szoftveripari vállalatok mind földrajzi, mind kapcsolati közelségben vannak, amely egyértelmúen alátámasztja, hogy lehetőség lenne egy müködő szoftveripari klaszter kialakulására. Ehhez azonban elengedhetetlen olyan további feltételek megteremtése, mint:

- a támogató, de nem domináló kormányzati szerep érvényesülése;

- a kölcsönös előnyöket nyújtó innovatív kapcsolatrendszer és partnerség kiépülése a vállalatok, egyetemek és kutatóintézetek között;

- olyan szoftveripari részterületek létrehozása, ahol a vállalatok nem csak eseti jelleggel, hanem folyamatosan együtt tudnak múködni.

A kevésbé fejlett régiókban az iparág fejlödésének forrását jelentheti a más helyi iparágaktól - a térségben biotechnológia, orvostudomány - érkezett megrendelések és a számukra biztosított informatikai háttéralkalmazások kifejlesztése. Az iparágak közötti együttmüködések is a földrajzi és a kapcsolati közelség által együttesen nyújtott előnyökre épülve fejlödhetnek. 


\section{Összegzés}

Szeged és vonzáskörzetében egy szoftveripari klaszter kialakulási esélyeinek vizsgálatát indokolttá tette, hogy a kevésbé fejlett Dél-alföldi régió „tudásszigetét” alkotó város szoftveriparban országos szinten is kiemelkedő. A vállalatok fizikai, földrajzi közelsége előnyt biztosít a tudás áramlásában, az innovációban és részben a költségek csökkentésében is. A felmérés igazolja, hogy mind üzleti, mind pedig nem-üzleti kapcsolatokon alapuló szerveződések létrejönnek a szegedi szoftveripari vállalatok és egyéb szervezetek között, ami pozitív hatással van az innovációs tevékenységükre, vállalkozókészségükre, szakmai fejlődésükre.

Beigazolódott, hogy az együttműködések létrejötte nem csak a földrajzi közelségre, hanem a kapcsolatok informális jellegére, a vállalatok kapcsolati közelségére is visszavezethető. A földrajzi közelség kulcsfontosságú a szegedi vállalatok fejlődésében és a szoftveripari tevékenységek folytatásában, az információ és tudás (kiemelten a tacit tudás) átadásában, de ennek mértéke nem kezelhetố elkülönülten a kapcsolati közelségtöl:

- szükség van a külső (föleg fövárosi) megrendelésekre és a régión kívüli partnerektől származó külső tudásforrásokra, mely kapcsolatok kiépülésének alapját a kapcsolati közelség jelenti,

- a szoftveripar egy speciális eset, ahol a termékek szellemi termékek, amelyek fejlesztése földrajzilag távol levő egységeken belül is folyhat, és digitális eszközök révén bárhová eljuttathatóak, azaz távmunkában lehet dolgozni, pl. fövárosi cégek részére,

- a vállalati együttmüködésekhez szükséges személyes, face to face megbeszélések eseti jellegủek, informatikai és kommunikációs eszközök által elösegítettek.

Kiderült, hogy a vállalatok szubjektív értékelése alapján a földrajzi közelség szerepe a szoftveriparban viszonylagos és nem állandó feltétele a közös kutatási projektek megvalósulásának. A fơldrajzi közelségre szükség van a szoftveripari tevékenységek folytatásához, de ennek igénye nem független a kapcsolati közelségtől, a vállalatok közös szakmai nyelvezetétöl, ismereteitől, rutinjaiktól, kulturális hátterüktól. A vállalatok ennek köszönhetően a régión kívüli partneri kapcsolatok széles bázisát építik ki, sokoldalú fejlesztési együttmüködést hoznak létre egyetemekkel és kutatóintézetekkel. Innovációs tevékenységüket szakképzett munkaerőbázisuk, kiépített üzleti és személyes kapcsolatrendszerük befolyásolja. Az információk és a tudás terjedésében szerepet játszó személyes kapcsolatok társadalmi beágyazottságának, a közös értékekkel és tudásbázissal való rendelkezésnek kiemelt szerepe van.

A vállalatok innovativitását és tudásintenzitását a kapcsolati közelség egyes dimenzióinak erőssége együtt és külön-külön is meghatározza. A vállalatok közötti kapcsolatok, az együittmüködési hajlandóság, a közös munkaerö- és tudásbázis annak lehetôségét biztosítja, hogy Szegeden és vonzáskörzetében szoftveripari klaszter alakuljon ki. A klaszterépítéshez szükséges feltételek részben már kiépültek a térségben, részben pedig a kapcsolati közelség dimenzióinak további megerősítése révén és tudatos fejlesztési stratégia által kialakíthatók. 


\section{Jegyzet}

${ }^{1}$ Tanulmányom a 2009. évi OTDK Közgazdaságtudományi Szekció Regionális Gazdaságtan I. tagozatának I. díjat nyert, „A közelség szerepe az IT klaszterek kialakulásában (Szegeden és vonzáskörzetében)" címủ dolgozat (konzulens: Lengyel Imre) átírt és módosított változata.

\section{Irodalom}

Albino, V.-Carbonara, N.-Petruzzelli, A.M. (2007) Proximity as a Communication Resource for Competitiveness: A Rationale for a Technology Cluster. - International Journal of Learning and Intellectual Capital. 4. 430-452. o.

Boschma, R.A. (2005) Proximity and Innovation: A Critical Assessment. - Regional Studies. 1. 61-74. o.

Capello, R.-Faggian, A. (2005) Collective Learning and Relational Capital in Local Innovation Processes. - Regional Studies. 1. 75-87. o.

CCC (2005) Strategic Cork. Guide to the city's investment opportunities, quality of life, plans for the future. Cork City Council, Cork. Ireland.

Congress Oulu (2006) Oulu - a five start technology cluster. Meet Oulu Hitech, Oulu.

CSKI (2002) ICT in the Czech Republic: Institutions, Regulations, Challenges and Apllications in Academia, Industry and the Public Sector. Czech Society of Cybernetics and Informatics, Prága.

Gallaud, D.-Torre, A. (2004) Geographical Proximity and Circulation of Knowledge through Inter-firm Cooperation. Palgrave, Macmillan, London.

Grosz, A. (2006) Klaszterek és támogatásuk az Európai Unióban és Magyarországon. - Lengyel I.Rechnitzer J. (szerk.) Kihivások és válaszok: A magyar épitöipari vállalkozások lehetöségei az Európai Uniós csatlakozás utáni idöszakban. NOVADAT Kiadó, Győr.

Grosz A.-Rechnitzer J. (2005) Régiók és nagyvárosok innovációs potenciálja Magyarországon. MTA RKK, Pécs-Györ.

ISM (2006) Study into the strategies, policies and other conditions needed to allow the European-based Software and Service industries to take global platform leadership. Information Society and Media. Directorate General, Berlin.

Kirat, T.-Lung, Y. (1999) Innovation and proximity. Territories as loci of collective learning processes. European Urban and Regional Studies. 6. 27-38. o.

Knoben, J.-Oerlemans, L.A.G. (2006) Proximity and inter-organization: A literature review. International Journal of Management Reviews. 8. 71-89. o.

Krugman, P. (2000) A földrajz szerepe a fejlödésben. - Tér és Társadalom. 4. 1-21. o.

Lagendijk, A.-Lorentzen, A. (2007) Proximity, Knowledge and Innovation in Peripheral Regions. On the Intersection between Geographical and Organizational Proximity. - European Planning Studies. 4. 457-466. 0 .

Lengyel I. (2001) Iparági és regionális klaszterek: tipizálásuk, térbeliségük és fejlesztésük fổbb kérdései. Vezetéstudomány. 10. 19-43. o.

Lengyel I. (2003) Verseny és területi fejlödés: térségek versenyképessége Magyarországon. JATEPress, Szeged.

Lengyel I. (2006) A Szegedi Tudományegyetem lehetőségei a tudásalapú helyi gazdaságfejlesztésben. Máder B.-Rácz B. (szerk.) Szegedi Tudományegyetem: 85 éves szegedi felsổoktatás. Szegedi Tudományegyetem, Szeged. 53-74. o.

Lengyel I. (2008) A kôzelség alakváltozásai a tudásalapú helyi gazdaságfejlesztésben. - Lengyel I.Lukovics M. (szerk.) Kérdőjelek a régiók gazdasági fejlödésében. JATEPress, Szeged, 109-129. o.

Lengyel I.-Mozsár F. (2002) A külső gazdasági hatások (externáliák) térbelisége. - Tér és Társadalom. 2. $1-20.0$.

Lengyel I.-Rechnitzer J. (2004) Regionális gazdaságtan. Dialóg Campus Kiadó, Budapest-Pécs.

Morris, D.-Donnelly, T.-Hyry, M. (2005) The Oulu Phenomenon. - Regional Association International Conference. Aalborg, Denmark.

Nemes Nagy J.(2009) Terek, helyek, régiók. A regionális tudomány alapjai. Akadémiai Kiadó, Budapest. OECD (2000) Irish ICT Cluster. OECD Cluster Focus Group Workshop, Utrecht. Netherlands.

Patik R.-Deák Sz. (2005) Regionális klaszterek feltérképezése a gyakorlatban-Tér és Társadalom. 3-4. 139-158. o. 
Porter, M.E. (1990) The Competitive Advantage of Nations. The Free Press, New York.

Porter, M.E. (1998) Clusters and the new economics of competition. - Harvard Business Review. November-December. 77-90. o.

Porter, M.E. (2000) Location, Clusters, and Company Strategy. - Clark, G.L.-Feldman, M.P.-Gertler, M.S. (eds.) The Oxford Handbook of Economic Geography. Oxford University Press, Oxford. 253-274. o.

Rechnitzer J.--Smahó M. (szerk.) (2007) Unirégió. Egyetemek a határ menti együttmüködésben. MTA Regionális Kutatások Központja, Pécs-Győr.

Tartu Region (2007) IT Sector overview. Information Technology: Smartware from Tartu, Estonia. Tartu City Goverment, Tartu.

Torre, A.-Gilly, J-P. (2000) On the Analytical Dimension of Proximity Dynamic. - Regional Studies. 2. 169-180. o.

Torre, A.-Rallet, A. (2005) Proximity and localization. - Regional Studies. 1. 47-60. o.

Varga, A. (2006) The Spatial Dimensions of Innovation and Growth: Empirical Research Methodology and Policy Analysis, - European Planning Studies. 9. 1171-1186. o. 